\title{
Interleukin-7 and immune reconstitution in cancer patients: a new paradigm for dramatically increasing overall survival
}

\author{
Michel Morre • Stéphanie Beq
}

Received: 26 August 2011 / Accepted: 16 January 2012 / Published online: 2 March 2012

(C) The Author(s) 2012. This article is published with open access at Springerlink.com

\begin{abstract}
Although great effort is being expended in the development of cancer immunotherapies, it is surprising that global lymphopenia and its various dimensions are not being systematically assessed in cancer patients. The incident pathologies associated with various immunosuppressed conditions such as those found in HIV infection have taught us that measuring various $\mathrm{T}$ cell populations including CD4 provides the clinician with a reliable measure for gauging the risk of cancer and opportunistic infections. Importantly, recent data emphasize the key link between lymphocyte $T$ cell counts and overall survival in cancer patients receiving chemotherapy. Treatment of immunocompromised patients with interleukin-7 (IL-7), a critical growth and homeostatic factor for $\mathrm{T}$ cells, has been shown to produce a compelling profile of $T$ cell reconstitution. The clinical results of this investigational therapy confirm data obtained from numerous preclinical studies and demonstrate the long-term stability of this immune reconstitution, not only on CD4 but also on CD8 $\mathrm{T}$ cells, involving recent thymic emigrants as well as naive, memory, and central memory $T$ cells. Furthermore, IL-7 therapy also contributes to restoration of a broadened diversity of the $\mathrm{T}$ cell repertoire as well as to migration of these cells to lymph nodes and tissues. All these properties support the initiation of new clinical studies aimed at reconstituting the immune system of cancer patients before or immediately after chemotherapy in order to demonstrate a potentially profound increase in overall survival.
\end{abstract}

M. Morre $(\triangle) \cdot S$. Beq

Cytheris S.A.,

175 rue Jean Jacques Rousseau,

92130 Issy-Les-Moulineaux, France

e-mail: mmorre@cytheris.com

S. Beq

e-mail: sbeq@cytheris.com
Keywords IL-7 · Immunotherapy · Cancer - Immune reconstitution

\section{Introduction}

Numerous articles have been devoted to reviewing the immune properties of interleukin-7 (IL-7) and this molecule's potential for therapeutic use. The most recent of these articles provides a comprehensive review of these therapeutic avenues along with the supportive immune rationale [1]. Taking a more focused approach, we here intend to delve into the specific problem of lymphopenia in the oncology patient, first analyzing its major aspects and pathological consequences and then demonstrating how recombinant IL7 represents a potentially effective therapy for treatment of this condition and a solution to a longstanding medical problem.

The immune status of cancer patients: poorly monitored and often ignored

Although it might seem obvious that tracking immune system status is crucial to inhibiting carcinogenesis and maintaining cellular homeostasis [2], many cancer patients are surprisingly more immunocompromised than suspected by their treating physician. In fact, with the exception of patients receiving hematopoietic stem cell transplants (HSCT) for treatment of hematologic malignancies, the immune status of cancer patients is rarely evaluated and when attempted, is frequently done poorly.

When oncologists do measure absolute lymphocyte counts, they do not usually evaluate T cell (CD3) numbers, rarely measure $\mathrm{T}$ cell helpers (CD4), and only exceptionally, 
evaluate the other $\mathrm{T}$ cell subpopulations and the breadth of the $\mathrm{T}$ cell receptor (TCR) repertoire. As a result, until recently, the potential consequence of lymphopenia and its association with overall patient survival was poorly documented. In fact, this is often the case when a biomarker is not expected to change with an approved therapeutic intervention. If neutrophil counts are monitored, it is partly due to the fact that corrective measures can be undertaken through G-CSF administration with the same being true for platelets with blood transfusion and red blood cells utilizing therapy with erythropoietin.

Although the deficit of specific or local anti-tumor response had been intensively explored, prior to 2003 most data aimed at evaluating the global immune deficit of cancer patients came from Mackall's team in the USA and the Blay/ Ray-Coquard's team in France. In two landmark papers, Mackall et al. [3, 4] explored the immune reconstitution of young patients who had undergone intensive chemotherapy for cancer. In their published studies, the Mackall team demonstrates that $\mathrm{CD} 4 \mathrm{~T}$ cell reconstitution occurs primarily in children while young adults exhibit deficiencies in this pathway. This suggests that rapid $\mathrm{T}$ cell regeneration requires residual thymic function in these patients, while $\mathrm{CD} 8$ recovery is much faster and less dependent of thymic activity. Between 1996 and 2004, Blay et al. conducted various studies demonstrating a relationship between early lymphopenia (absolute lymphocyte count (ALC) $<700 / \mathrm{mm} 3$ ) from days 1 to 5 following chemotherapy and the risk of febrile neutropenia. In another study, they were also able to identify a direct link between CD4 lymphopenia, febrile neutropenia, and early death after cytotoxic chemotherapy [5-7]. Since lymphopenia-inducing cytotoxic drugs are the mainstay of cancer treatment, a better understanding of the immune system's ability to restore a depleted $\mathrm{T}$ cell pool is clearly of critical importance.

\section{The various aspects of lymphopenia: a multi-dimensional problem}

\section{Cell counts and intensity of response}

The combined use of monoclonal antibodies and fluorescence-activated cell sorting now allows for easy tracking of changes in peripheral blood $\mathrm{T}$ cells and enables the quantification and analysis of immune deficit or immune reconstitution by cell function (helpers and cytotoxic $\mathrm{T}$ lymphocytes (CTLs)), recent history (RTEs, naïve, and memory), or status (functional, activated, or exhausted). In the clinical setting, these convenient tools are used as key biomarkers in following the immune status of patients and the effects of drug therapy. Due in part to greater awareness of the importance of measuring CD4 levels as a consequence of the HIV epidemic, absolute CD4 lymphocyte counts though readily obtained by the clinician are not often requested by oncologists. Multiple large cohort studies of HIV patients have documented the medical value of tracking CD4 $\mathrm{T}$ cell counts for monitoring health status. These studies clearly indicate that only those patients with CD4 counts above 500/ $\mu 1$ have a life expectancy comparable to the HIV naive population [8-10]. And, in a study which holds great significance for cancer patients, the stratification of these HIV patients according to their CD4 count demonstrates a clear link with the incidence of AIDS and non-AIDS-related malignancies [11].

\section{Cell variety and coordination of response}

Unlike anemia, immune deficit is not a single-cell-type deficit and thus requires a full evaluation encompassing the measurement of $\mathrm{T}$ and $\mathrm{B}$ cell counts as well as the main subpopulations including naive, effector, memory, and central memory cells along with the biomarkers of their functionality. Each subpopulation has a specific function and it is the coordination of these functions that makes up the immune response. A deficit in a specific subpopulation will abrogate the response. Investigations of HIV disease have demonstrated the importance of CD4 help and vaccine studies have emphasized the role of long-term central memory $\mathrm{T}$ cells. Other T cells like $\mathrm{T} \gamma \delta$ and NKT also appear critical for triggering or enhancing anti-tumor responses, an attribute primarily associated with their ability to articulate innate and adaptive immunity.

The distribution of $\mathrm{T}$ cell subpopulations differs substantially between patients with and without cancer, increasingly so at more advanced stages of disease and in those patients who have undergone treatment. Heavily treated patients show a relative shrinkage of the naïve and central memory $\mathrm{T}$ cell populations but with increased proliferation and differentiation in the direction of effector memory $\mathrm{T}$ cells, a state described as T cell exhaustion [12].

The complete coordination of the immune response requires the production and homeostasis of these subpopulations indicating that a good immune reconstitution must encompass most if not all of these cell phenotypes.

\section{Cell polyclonality and breadth of response}

$\mathrm{B}$ and $\mathrm{T}$ cells represent a vast array of immune competent cells, each with a specific receptor (BCR or TCR) restricting its activation to a specific antigen presented in the context of MHC molecules. This specificity implies that to confer sufficient immune protection against infectious agents and malignant cells, a $\mathrm{T}$ cell population must include enough diversity in the TCR repertoire to ensure a broad range of response to various pathogenic antigens. This is particularly 
important in controlling viruses and malignant cells which have the ability to mutate and thereby escape control of the immune system. Similarly, in the treatment of cancer patients, tumors are known to escape control of the immune system by mutation. For example, under a concept known as immunoediting [13] which is directed towards tumor elimination, the relative level of control by or escape from $T$ cells is determined by the relative pressure from the immune system. Not surprisingly, the broader the repertoire of $\mathrm{T}$ cells the better the control.

Through modern PCR-based technologies, it is now possible to measure the diversity of the TCR repertoire. ImmunID Technologies (Grenoble, France), a company focused on the development of this technology, has proposed the word "divpenia" to refer to the low diversity of the TCR observed in pathologies such as those represented by chronic viral disease and cancer [14]. The company has accumulated data showing that although divpenia is frequently associated with low CD4 or CD3 counts, this is not a systematic relationship and patients with reasonable $\mathrm{T}$ cell counts can present with a very narrow repertoire, most likely reflecting insufficient thymic function. Interestingly, in various cohorts of HIV patients, when the latest CD4 count does not appear as a good prospective or retrospective indicator of patient health status, the nadir CD4 count clearly reflects this status, indicating the extension of past thymic and mucosal damage produced by HIV infection [15].

The extensive literature on cancer immunoediting supports the importance of analyzing the breadth of T cell TCR repertoire and the inherent breadth of $\mathrm{T}$ cell responses and control. This also emphasizes the need for a therapeutic agent able to protect and/or regenerate thymic functions.

\section{The local deficit in the deep compartment and the need for trafficking in lymphoid cells}

Although counts and analysis of peripheral $\mathrm{T}$ cells can reflect the status of $\mathrm{T}$ cells in the deeper lymphoid organs and tissues, this is not a systematic relationship. Many of the $T$ cell dysfunctions seen in liver biopsies of chronic hepatitis $\mathrm{B}$ virus (HBV) and hepatitis $\mathrm{C}$ virus (HCV) patients are not readily discernible in peripheral T cells. In HIV infection, it took almost 20 years for the medical community to understand the significance of severe lymphopenia in the gut and its key role in the persistence of $\mathrm{T}$ cell activation $[16,17]$. Even more recently, fibrosis in the lymph nodes of HIV patients has been shown to be connected to poor immune reconstitution [18].

The immune system is largely composed of mobile cells which need to traffic and interact in order to recognize pathogenic antigens, emit an elimination message, trigger a response, and then target and eliminate the pathogen. The coordination and final outcome of these cellular functions implies the trafficking of cells from the pathogen recognition site to the lymphoid organ and back to the pathogen elimination site. Homing of $\mathrm{T}$ cells to lymphoid organs, tissues, and tumors requires the critical expression of chemokines and integrins. In the absence of this expression, $\mathrm{T}$ cells will not migrate according to their programmed functions and the immune response will stop due to a lack of good trafficking to condition their interactions and coordinate the sequence of their functions.

These data seen in the context of chronic viral infection have considerable consequences for cancer treatment and serve to further emphasize the need to assess the "local lymphopenia" within the tumor or its immediate vicinity. Neutralization of TGF $\beta$ to control fibrosis, which blocks access to the tumor, is the key to driving the anti-tumor immune response and providing $\mathrm{T}$ cells full access to malignant cells. Multiple preclinical models have demonstrated that $\mathrm{T}$ cell infiltration is critical to tumor elimination, including $\mathrm{T}$ cell mucosal infiltration in the area surrounding the tumor.

Due to the variety of $\mathrm{T}$ cell populations and functions, lymphopenia is not a single-dimensional problem. Accordingly, immune reconstitution should encompass all these dimensions in order to guarantee the intensity, breadth, rapidity, and stability of the immune responses as well as the quality of immune reconstitution.

\section{The critical consequences of lymphopenia in assessment of cancer risk and prognosis}

Lymphopenia and an increased risk of cancer

Clinical conditions associated with immune deficit show that this condition is indicative for patient health status and incidence of malignancies. In a landmark meta-analysis study, Grulich et al. compared the incidence of cancers in two populations of immunosupressed patients, HIV-infected patients, and the transplant recipients [19]. The study showed an increased incidence and similar distribution pattern of cancers in both populations, underscoring the high incidence of cancers known to have an infectious cause: the three AIDS defining malignancies, all HPV-related, Hodgkin's lymphoma, liver, and stomach cancers [19]. The authors go on to conclude that it is immune deficiency rather than any other risk factor that drives the incidence of cancer in these two populations.

With more than 10 years of experience in treating HIV patients with highly active antiretroviral therapy (HAART), a therapy which affords recovery of CD4 $\mathrm{T}$ cell counts in most patients after 2 to 4 years of treatment ( $>60 \%$ ), figures now also show that HIV patients have an increased risk of 
non-AIDS defining malignancies (NADM), most likely due to the poor quality of their immune reconstitution. This was recently illustrated in a cohort study by Dauby et al. who found that age $(>45)$ and nadir CD4 counts $\left(<200 / \mathrm{mm}^{3}\right)$ are associated with an increased incidence of NADM [20].

Lymphopenia and poor overall survival in cancer patients

Oncologists have now started to more systematically measure ALC and to explore the link with disease progression. In 2009, Ray-Coquard et al. published a multi-cohort analysis of patients with breast cancer (BC), soft tissue sarcoma (STS), and non-Hodgkin lymphoma (NHL). The study found that lymphopenia (ALC $<1,000 / \mu \mathrm{l} / \mathrm{L}$ ) was present in approximately $25 \%$ of the patients and was associated with markers of disease progression and poor overall survival: median 10 versus 14 months in BC, 5 versus 10 months in STS, and 11 versus 94 months in NHL [21]. The authors conclude that lymphopenia is an independent prognostic factor for overall progression-free survival in several cancers.

In 2010, Porrata et al. studied the relapse rate of 149 Mayo clinic patients with diffuse large B cell lymphoma treated with rituxan, cyclophosphamide, adrimamycine, vincristine, and prednisone [22]. Relapse was associated with lower ALC (1,430 vs 670 cells $\left./ \mathrm{mm}^{3}\right)$ and patients with ALC $>960$ cells $/ \mathrm{mm}^{3}$ had a cumulative incidence of relapse of $6 \%$ versus $79 \%$ with an ALC $<960$.

In 2011, Cézé et al. conducted a retrospective study on the influence of lymphopenia as a prognostic marker of colorectal cancer in patients receiving chemotherapy [23]. Among the 260 patients analyzed, lymphopenia (ALC $<1,000$ cells $/ \mathrm{mm}^{3}$ ) appeared as an independent factor for hematological toxicity and was associated with shorter overall survival (median 16 vs. 24 months).

At the recent ASCO meeting, three abstracts showed the association of lymphopenia with a poor outcome: Lim et al. [24] poor overall survival in stage IV advanced gastric cancer; Desposorio et al. [25] faster progression of preoperative breast cancer; and, Capellino et al. [26] poor survival in locally advanced breast cancer. In another set of data, Peron et al. [27] presented the significant association of various $\mathrm{T}$ cell counts $(\mathrm{CD} 3, \mathrm{CD} 4$, and CD8) observed prior to initiation of chemotherapy with survival in lymphoma, breast cancer, and sarcoma.

This encouraging result obtained on ALC or T cell counts led the Blay/Ray-Coquard team to further document CD4 T cell counts in various populations of cancer patients, including breast cancer, and to further explore the diversity of the TCR repertoire in collaboration with ImmunID Technologies. An interim analysis of a prospective breast cancer cohort currently under evaluation was presented at the 2011 AACR meeting, indicating a striking difference in the 9-month survival rate of patients with more than 450 $\mathrm{CD} 4 / \mathrm{mm}^{3}$ or more than $20 \%$ diversity of their TCR repertoire $\left(83 \%\right.$ for CD $4>450 / \mathrm{mm}^{3}$ vs $45 \%$ for CD $4<450 / \mathrm{mm}^{3}$ and $78 \%$ for TCR diversity $>20 \%$ vs $17 \%$ for TCR diversity $<20 \%$ ) (AACR 2011 abstract 165).

All these interesting observations shed new light on cancer-related hemato-toxicity and its impact on overall survival of cancer patients, further emphasizing the protective role of the immune system in fostering the anti-infective and anti-malignant aspects of immune surveillance.

Lack of $\mathrm{T}$ cell intra-tumoral infiltration: lymphopenia and dysfunction associated with poor outcome

In 1984, Miwa was the first to review the data linking cancer prognosis with tumoral $\mathrm{T}$ cell infiltration, indentifying the enumeration of tumor-infiltrating lymphocytes (TIL) as a good prognostic biomarker [28]. The local availability of the family of LEU and OKT monoclonal antibodies explains the interest of Japanese teams in this marker [29, 30]. Since that time, the topic has been broadly documented and continuously reviewed [31-34], the case of colorectal cancer perhaps being one of the best documented. Presented in a landmark paper in 1995, Pages et al. established the association between increased survival and a high level of infiltrating memory $\mathrm{T}$ cells $(\mathrm{CD} 45 \mathrm{RO}+)$, an absence of signs of early metastatic invasion, and a less advanced pathological state [35]. In more recent papers, an effort is made to better document the various phenotypes of the TILs, emphasizing the need to document their functional status.

Among TILs the ratio of suppressor FoxP3 regulatory $\mathrm{T}$ (Treg) cells over their agonist CD8 or CD4 counterparts is critical to delineating the prognosis which is linked to the number of cells able to express or support a CTL activity $[36,37]$. Also of interest is tracking the known "protein programmed death 1" (PD1) expressed on activated T cells. The engagement of the programmed death ligand 1 (PDL1)/B7H1 within tumor cells or other host-derived cells results in the down regulation of $\mathrm{T}$ cell function and represents an important negative regulatory pathway $[38,39]$.

\section{IL-7 for immune reconstitution: preclinical data}

IL-7 was identified as a human T cell growth factor in 1987 [40]. The origin of circulating IL-7 is not completely elucidated as it can apparently originate from various organs. What is definitively known is that it is produced in lymphoid organs by thymic hepithelial cells, bone marrow stromal cells and, in non-lymphoid organs, by liver and intestinal epithelial cells, keratinocytes, and fibroblasts. In lesser amounts, dendritic cells and macrophages can also produce IL-7 (see for a review [41]). In solid tissue, IL-7 is 
bound/presented at the surface of T cells by fibronectin and heparin sulfate [42]. The IL-7 receptor is only present on the cell surfaces of hematopoietic lineage, including $\mathrm{T}$ cells, dendritic cells, macrophages, and NK subsets. Recently, the known biology of IL-7 has been well summarized in an excellent review by Fry and Mackall [1], allowing us here to confine ourselves to emphasizing a few points seen as critical to the therapeutic use of IL-7.

\section{IL-7 is key for T cell production and homeostasis}

IL-7 is a non-redundant cytokine essential for $\mathrm{T}$ cell production. Indeed, IL-7/IL-7 R gene knockout (KO) mice do not produce mature $\mathrm{T}$ cells $[43,44]$. In these models, the thymocytes are blocked at an early stage of differentiation and thymus cellularity is dramatically reduced. In vitro studies showing the essential role of IL-7 in establishing a competent immune system in humans [45] were confirmed by a few SCID (severe combined immunodeficiency disease) syndrome cases [46-49].
These patients presented a profound $\mathrm{T}$ cell deficiency due to a defect in the IL-7 receptor leading to an incapacity for binding to the cytokine or for signal transduction. IL-7 is also a major player in the regulation of peripheral $\mathrm{T}$ cell homeostasis [50], as demonstrated in 2001 by Fry et al. [51] and Napolitano et al. [52] who show the inverse relationship between endogenous blood levels of IL-7 and counts of CD4 T cells in HIV-infected patients, a feedback regulation already documented for erythropoietin in anemic patients. Furthermore, IL-7 is also implicated in the survival, proliferation, differentiation, and metabolism of peripheral $\mathrm{T}$ cells $[53,54]$.

Thus, IL-7 is seen as a critical factor for T cell production, maturation and expansion and therefore an ideal candidate for immune reconstitution. This non-redundant function of IL-7 for T cell production and maintenance is very similar to erythropoietin for red blood cells, PDGF for platelets and G-CSF for neutrophils, and provides a solid basis for the development of a therapeutic product (Fig. 1).

\section{IL-7 Boosts Immune Response by acting at many levels of Lymphocyte Maturation}

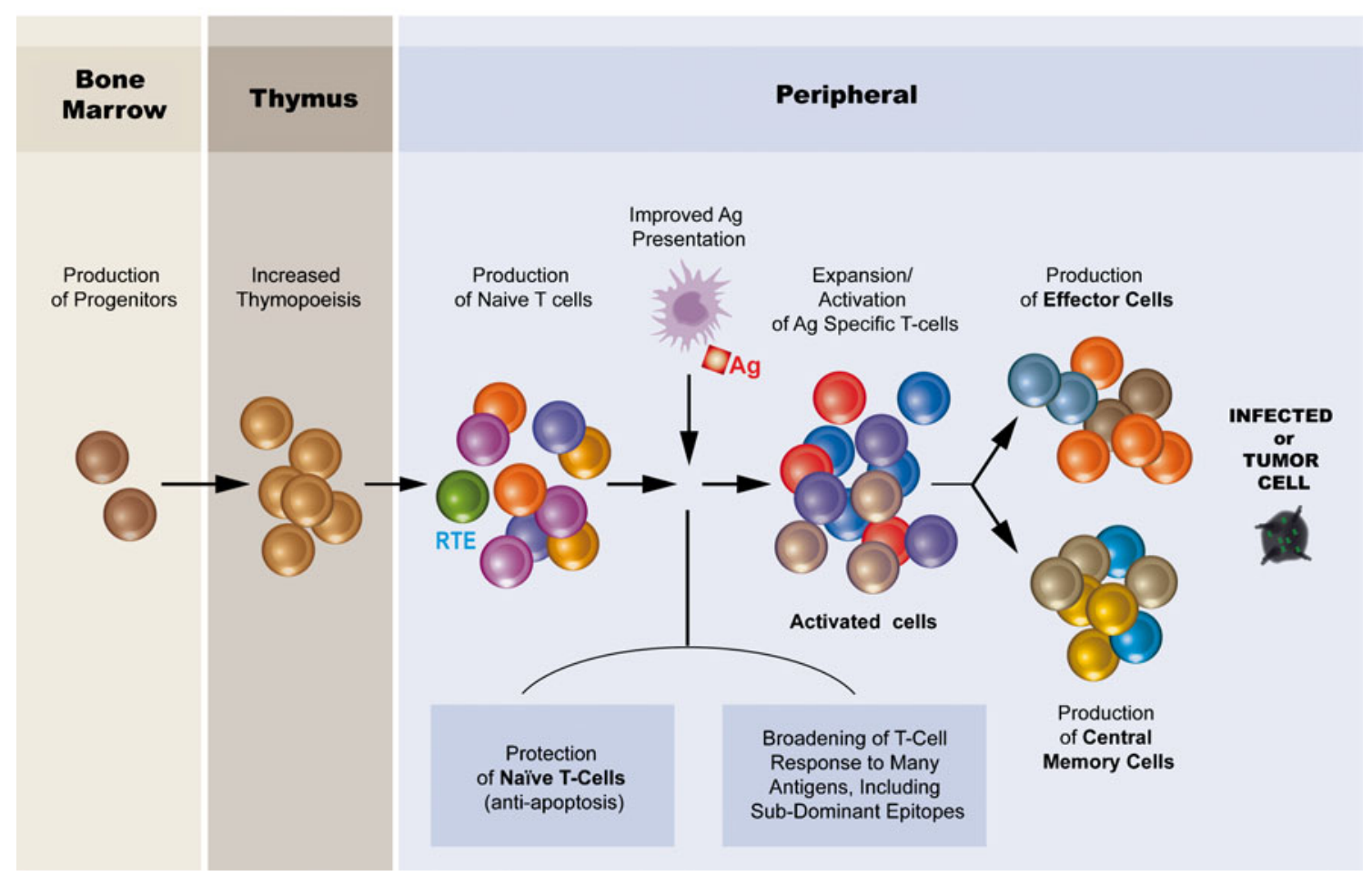

Fig. 1 IL-7 a key factor in thymopoiesis and T cell periperal homeostasis. IL-7 receptor is expressed on common lymphoid progenitors (CLP) cells in the bone marrow and is essential for maintenance or progenitor pool for both B and T cells. During T cell development in the thymus IL-7 is involved at different stages of $\mathrm{T}$ cell proliferation and positive/negative selection. Following thymic export, recent emigrant T cells (RTE) are incorporated to the periphery. In the periphery, IL-7 is a major anti-apoptotic/survival factor of T cells through elevation of Bcl-2 expression. It also controls homeostatic and antigen- driven expansion of both CD4 and CD8 T cells. Its capacity to augment the immune response to weak or low affinity antigens will lead to the recognition of tumoral antigens. The Th1 response directly target tumoral cells. Following antigen driven expansion of activated T cells, a small population of effector cells become long-lived memory $\mathrm{T}$ cells expressing high levels of IL-7 receptor, the long-lasting anti-tumoral response. IL-7 by controlling thymopoiesis and peripheral homeostasis as well as antigen response is a critical factor for the immune system 


\section{IL-7 key preclinical results support its therapeutic use}

IL-7 efficiently triggers immune reconstitution in various models of lymphopenia

Very early in its development, IL-7 was successfully tested in various models of immune reconstitution. In mice, using a single injection of cyclophosphamide, Morisey et al. induced lymphopenia and showed that IL-7 administration resulted in an accelerated recovery of peripheral CD4+ and $\mathrm{CD} 8+\mathrm{T}$ cell numbers in the spleen and lymph nodes [55]. Alpdogan et al. [56] demonstrated the immune reconstitution effects of IL-7 administration in a mouse model of allogeneic HSCT and Storek et al. did the same in a baboon model of autologous transplant [57]. This impressive immune reconstitution potential is also well documented in three reports on SIV-infected monkeys [58-60] and has more recently been shown to counteract interferon-induced lymphopenia [61]. In all these models, reconstitution involves both CD4 and CD8 lymphocytes as well as naïve and memory $\mathrm{T}$ cells.

\section{IL-7 does not induce an inflammatory cytokine storm syndrome}

In all in vivo preclinical models tested, IL-7 administration did not produce the acute inflammatory cytokine release observed with various other cytokines. During the preclinical toxicology studies conducted in macaques at very high doses (up to $1 \mathrm{mg} / \mathrm{kg}$ twice a week), IL-7 administration produced a massive expansion of $\mathrm{T}$ cells and accompanying infiltration of all lymphoid tissues accomplished as a cold infiltration without signs of inflammation or manifestations of acute cytokine storm. If IL-7 induces a massive expansion in most $\mathrm{T}$ cell populations this proliferation appears unlikely to be accompanied by $\mathrm{T}$ cell activation. This very probably reflects the quick internalization of the IL-7 receptor after IL-7 interaction leading to a transient refractoriness of the T cell to further IL-7 stimulation [62]. As demonstrated by Henriques et al., this is a feature of IL-7 that is very consistent with the disappearance of CD127+ cells and their reappearance after 5 to 7 days as observed in early IL-7 pharmacodynamic and pharmacokinetic studies conducted in monkeys [62]. This lack of T cell overactivation also accounts for the possibility of producing viable models of transgenic mice that over express IL-7, something which is impossible with most activating cytokines such as IL2, IL-12, and IL-15.

\section{IL-7 stimulates T cell homing to tissues}

Using the rhesus macaque primate model to investigate the mechanisms involved in the short-lived, initial peripheral $\mathrm{T}$ cell depletion observed after IL-7 administration, Beq et al.
[63] found that IL-7 administration induces a massive and rapid $\mathrm{T}$ cell migration from the blood into various organs, including the lymph nodes, parts of the intestine and the skin. This homing process is initiated after the induction of chemokine receptor expression by circulating $\mathrm{T}$ cells. In fact, all monkeys treated with IL-7 showed an increased expression of CD62L (L-selectin) and, when assessed, also showed an increase in $\alpha 4 \beta 7$ (MadCAM-1 integrin). Interestingly, in both anti-tumor responses discussed below, a massive tumor $\mathrm{T}$ cell infiltration was documented (Fig. 2).

The simultaneous production of CD4 and CD8 T cells contributes to restoring or expanding efficient immune responses

Observations of this set of immunological effects lead to the further testing of IL-7 in various preclinical tumor models. In these studies, it rapidly became apparent that IL-7 alone does not seem to trigger anti-tumoral immune responses. Instead, any such response triggered by a vaccine, an adoptive $\mathrm{T}$ cell therapy, or any therapy able to stimulate antigenpresenting cells (APC) is amplified and prolonged by IL-7 treatment, leading to an improved outcome in the animal model. Two of these vaccine models seem particularly suited for further investigations in the clinical setting.

In combining IL-7 administration with a GM-CSFsecreting tumor cell immunotherapy directed against colon carcinoma or malignant melanoma, $\mathrm{Li}$ et al. observed an increased number of activated dendritic cells, $\mathrm{T}$ cells in lymphoid tissues, and an increase of activated effector $\mathrm{T}$ cells in the tumor microenvironment. Importantly, this observation correlates with a more potent systemic tumorspecific $\mathrm{T}$ cell response leading to prolonged survival of the tumor-bearing mice [64].

In a complex double-transgenic mouse model using LCMV infection as a vaccine against a spontaneous SV40driven tumor mouse model, Pellegrini et al. observed that short term IL-7 therapy potently enhanced vaccine-mediated immunity, though it was inefficient in promoting antitumor immune responses in the absence of vaccination. To promote the anti-tumor response, IL-7 treatment was shown to antagonize various inhibitory networks, all of which are well documented at both the cellular and molecular level [65].

\section{IL-7 for immune reconstitution: clinical data}

The clinical development of recombinant human IL-7 follows two main pathways

In the setting of immunosuppression, usually associated with low to very low T cell counts, IL-7 is used for immune 


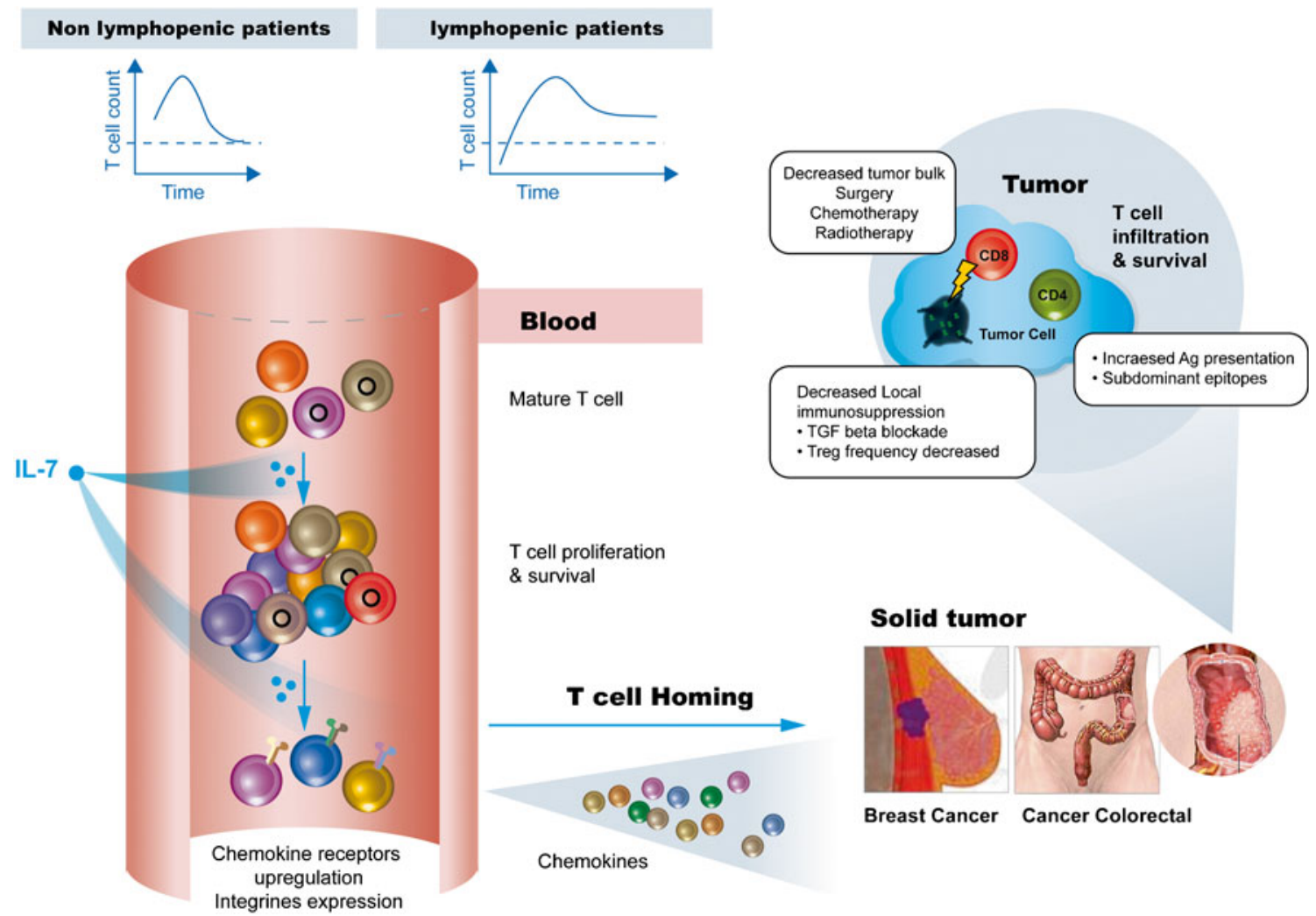

Fig. 2 Possible mechanisms of action of IL-7 immunotherapy in oncology. IL-7 immunotherapy increases both CD4 and CD8 T cell subsets (Levy et al.). In non-lymphopenic recipients, this increase is transient and return to baseline (unpublished data CONVERT study); while in lymphopenic patients, a progressive restoration was observable with a sustained higher $T$ cell count at 1 year post-treatment [74]. T-lymphocyte infiltration was demonstrated in lymph nodes, gut, and skin lymphoid tissue [60] in primates following IL-7 treatment. The cytokine lead to an upregulation of homing chemokine receptors on $\mathrm{T}$ cells including CXCR4, CCR6, and CCR9 coupled with increased chemokine levels in tissues (CCL19, CCL20, CCL21, and CCL25)

reconstitution. This setting includes HIV-infected patients who have not recovered adequate CD4 T cell counts after 1 or 2 years of HAART (the so-called "immune nonresponders"), post-HSCT patients who have received a cord blood transplant or grafted with CD34+ cells (both very poor in lymphocytes progenitors), patients with rare cases of idiopathic lymphopenia, and approximately $25 \%$ of postchemotherapy cancer patients. Soon, frequent cases of sepsis, where lymphopenia appears to be the main cause of the pathologic events leading to patient death, may also be classified in this group, along with patients exhibiting severe lymphopenia from any cause found in association with massive viral infections caused by pathogens usually controlled by a healthy immune system, including the EBV, CMV, HHV-6, and JC viruses.

Together, non-lymphopenic patients with chronic viral or bacterial infections or with cancer can benefit from IL7 treatment if it is combined with an additional therapy and plasma (CCL3, CCL4, and CXCL12). The teams of Li et al. and Pellegrini et al., elegantly demonstrated that IL-7 treatment of mice induces a massive $\mathrm{T}$ cell infiltration in murine tumor leading to an enhanced anti-tumor protection correlated with an increased number of activated dendritic cells [61, 62]. Moreover, IL-7 will decrease the immunosuppressive environment in the tumor by decreasing TGFbeta secretion a key cytokine for immunosuppressive Treg. By increasing the number of tumor reactive $\mathrm{T}$ including cells with a memory phenotype cells and decreasing immunosuppression will result in a persistent and long-lasting anti-tumor $\mathrm{T}$ cell response

utilized to create conditions favorable to the emergence of an immune response. This is exactly the case in chronic viral infections when a direct acting antiviral is used to decrease massive antigen load and thereby rescue some of the exhausted $\mathrm{T}$ cells expressing the $\mathrm{PD} 1^{+}$marker. This is also the case when another immune intervention such as a therapeutic vaccination is used to trigger the initiation of an immune response. Clinical studies in chronic $\mathrm{HCV}$ and HBV infections are currently ongoing to test this promising immune enhancement approach to IL-7 therapeutic use.

Rather than reviewing the IL-7 clinical effects by individual disease conditions, we will summarize below the main effects consistently observed in the clinical setting, illustrating the quality and the multiple dimensions of IL7-induced immune reconstitution. This better supports and justifies the current therapeutic approach utilized in treating cancer patients with IL-7. 
Distinct differences in IL-2 and IL-7 effects on T cells explain the failure of IL-2 in immune reconstitution

In advocating the development of IL-7 for immune reconstitution, the failure of IL-2 therapy in two major studies focused on the immune reconstitution of HIV patients represents an instructive opportunity for review of the main differences between these two cytokines. Like IL-7, interleukin-2 is a key cytokine component of the immune system responsible for regulating tolerance and immunity [66]. In designing HIV studies for IL-2, its known capacity for inducing T cell proliferation, and specifically CD4 T cell expansion, made it a logical drug candidate for HIV patients who suffered from the loss of peripheral and mucosal CD4 T cells. Yet, in attempting to restore CD4 $\mathrm{T}$ cell populations through IL-2 administration, results from two pivotal clinical studies, SILCAAT for extremely lymphopenic HIV patients and ESPRIT for the less lymphopenic HIV patients, failed to demonstrate any clinical benefit from this therapy, although patients did exhibit increased CD4 T cell counts [67].

A detailed phenotypic analysis [68] of the CD4 produced by IL-2 treatment explains the failure of these two studies. IL-2 delivers essential signals for thymic development of regulatory $\mathrm{T}$ (Treg) cells and later in the periphery promotes their homeostasis and function [69]. Treg cells are increased in most human solid tumors [70]. In murine models, selective elimination of Treg cells (i.e., CD4+CD25+FOXP3+) restores an effective anti-tumor immune response leading to tumor regression. Treg cells are now increasingly being studied in the oncology field due to their apparent ability to limit the potency of the $\mathrm{T}$ cell response directed against tumors, either physiologically or following immunotherapy. Recent work has demonstrated that Treg cells selectively activated in the tumor contribute to tumor progression [71]. Thus, IL-2 expansion of CD4+ Treg cells in HIV patients could not be expected to cure the deficit in conventional
$\mathrm{T}$ cells seen in this disease nor contribute to decreasing the incidence of opportunistic infections and AIDS or nonAIDS-related malignancies.

In fact, early transgenic models of IL-2 gene KO mice have shown, contrary to what is seen in the case of the IL-7 gene $\mathrm{KO}$, that this does not lead to SCID syndrome but rather to the development of a fatal immunopathology characterized by lymphoadenopathy, splenomegaly, $\mathrm{T}$ cell infiltration of the bone marrow, loss of $\mathrm{B}$ cells, anemia, and inflammation of the gut [72]. Furthermore, studies of IL-2R beta gene $\mathrm{KO}$ mice demonstrate that IL-2R beta is required to keep the activation programs of $\mathrm{T}$ cells under control, to maintain homeostasis, and to prevent autoimmunity [73]. Table 1 summarizes the various features of IL-2 and IL-7 immune effects.

Intensity: IL-7 therapy systematically and durably increases both CD4 and CD8 T cell counts

On the basis of data obtained from more than 200 patients treated with IL-7 in the clinical trials conducted by Cytheris, accumulated evidence indicates the potent lymphopoietic effect of this cytokine. The lymphopoietic response and peripheral expansion detected in all treated patients as a consequence of IL-7 therapy involves both CD4 and CD8 $\mathrm{T}$ cells. The CD4 $\mathrm{T}$ cells produced are conventional $\mathrm{T}$ cells with detectable helper function. Although IL-7 treatment induces a moderate increase in Treg, in relation to the increase of all other conventional $\mathrm{T}$ cells this increase actually translates into a decreased frequency of Treg. Interestingly, in HIV immune non-responders who have undergone several years of HAART therapy but whose CD4 counts remain below $250 / \mathrm{mm}^{3}$, a short 3-week cycle of IL-7 is sufficient to bring the CD4 counts of these patients above the threshold level of $500 / \mathrm{mm}^{3}$ and, furthermore, to maintain these CD4 counts above baseline levels for at least 1 year after this first cycle of IL-7 treatment. This long-lasting effect was also

Table 1 Comparison of immune effects of IL-7 and IL-2

\begin{tabular}{lll}
\hline & IL-7 & IL-2 \\
\hline $\begin{array}{ll}\text { Gene KO } \\
\text { Receptor gene KO confirmation }\end{array}$ & $\begin{array}{l}\text { Deletion of most T cells [43] } \\
\text { SCID syndrome in babies with mutation } \\
\text { of CD127/IL-7R [44] }\end{array}$ & $\begin{array}{c}\text { Hyper-proliferation of T cells, } \\
\text { autoimmune syndrome [73] }\end{array}$ \\
Production of CD8 T cells & +++ Long lasting [80] & NO [68] \\
Production of suppressor Treg & Very low, decrease in Treg frequency [81] & High, increase in Treg frequency [68] \\
THYMUS and repertoire & Support of thymopoietic activity broadening & NO thymic support [67] \\
Interaction with immunosuppressive TGF $\beta$ & of TCR repertoire [80, 82, 83] & Antagonism of TGF $\beta$ [77] \\
Life of produced T cells & Long lasting through anti-apoptotic support & Synergy with TGF $\beta$ for Treg production [84] \\
Clinical tolerance & {$[80,82,83]$} & Short \\
& Good: loss of IL-7R on activated T cells & Poor: risk of over-activation plus NK \\
protects from over-activation [80, 82, 83] & stimulation [67]
\end{tabular}


observed in lymphopenic patients, where the curve of T cell counts was observed to peak a few weeks after the IL-7 cycle, then drop to a plateau where it stabilized. The shape of this curve was different in non-lymphopenic patients, where the same treatment produced a temporary increase characterized by a dome shaped curve followed by a return to baseline after a few weeks.

Throughout the IL-7 dose escalation studies explored in various patient subpopulations, a dose-related effect from 3 to 10,20 , and $30 \mu \mathrm{g} / \mathrm{kg}$ was consistently observed. Considering the long-term maintenance of these effects, it appears that 10 and $20 \mu \mathrm{g} / \mathrm{kg} / \mathrm{week}$ provide the best results together with an optimal clinical tolerance. This is consistent with the pharmacokinetic of the product which appears to be linear up to $20 \mu \mathrm{g} / \mathrm{kg}$ but becomes non-linear beyond this point, probably reflecting a saturation of the high-affinity targetmediated clearance at $30 \mu \mathrm{g} / \mathrm{kg} / \mathrm{week}$.

From the data accumulated in immune-suppressed patients it is apparent that the most lymphopenic benefit is obtained from the $20 \mu \mathrm{g} / \mathrm{kg}$ dose level, at least as a first induction cycle. More clinical results will be needed to determine the benefit of the $10 \mu \mathrm{g} / \mathrm{kg} /$ week dose for which only preliminary results are available from the less immunosuppressed patients. This dose will be explored to determine its utility in the maintenance cycle of patients who have already received a first IL-7 cycle and have recovered a CD4 count that is above $400 / \mathrm{mm}^{3}$ (Levy, Y ICAAC 2009 abstract 3585; Perales, M-A ASH 2011 abstract 674).

This stable and combined increase of both CD4 and CD8 T cells is promising because CD8 T cells are known to be the best effectors of immune response. Thus, for these cells to be fully functional and migrate to the tumor site where they can then express their cytolytic activity they require the efficient CD4 support in which IL-2 and IL-21 production appears essential.

Quality and variety: IL-7 therapy impacts all T cells subtypes

IL-7 therapy increases both naive and memory T cells. The very significant increase of naïve $T$ cells also involves recent thymic emigrants (CD31+ bright). This increase in thymic output was also observed by measuring the production of $\mathrm{T}$ cell receptor excision circles (TRECs; small DNA excision circles produced during the recombination of the TCR and reflecting the
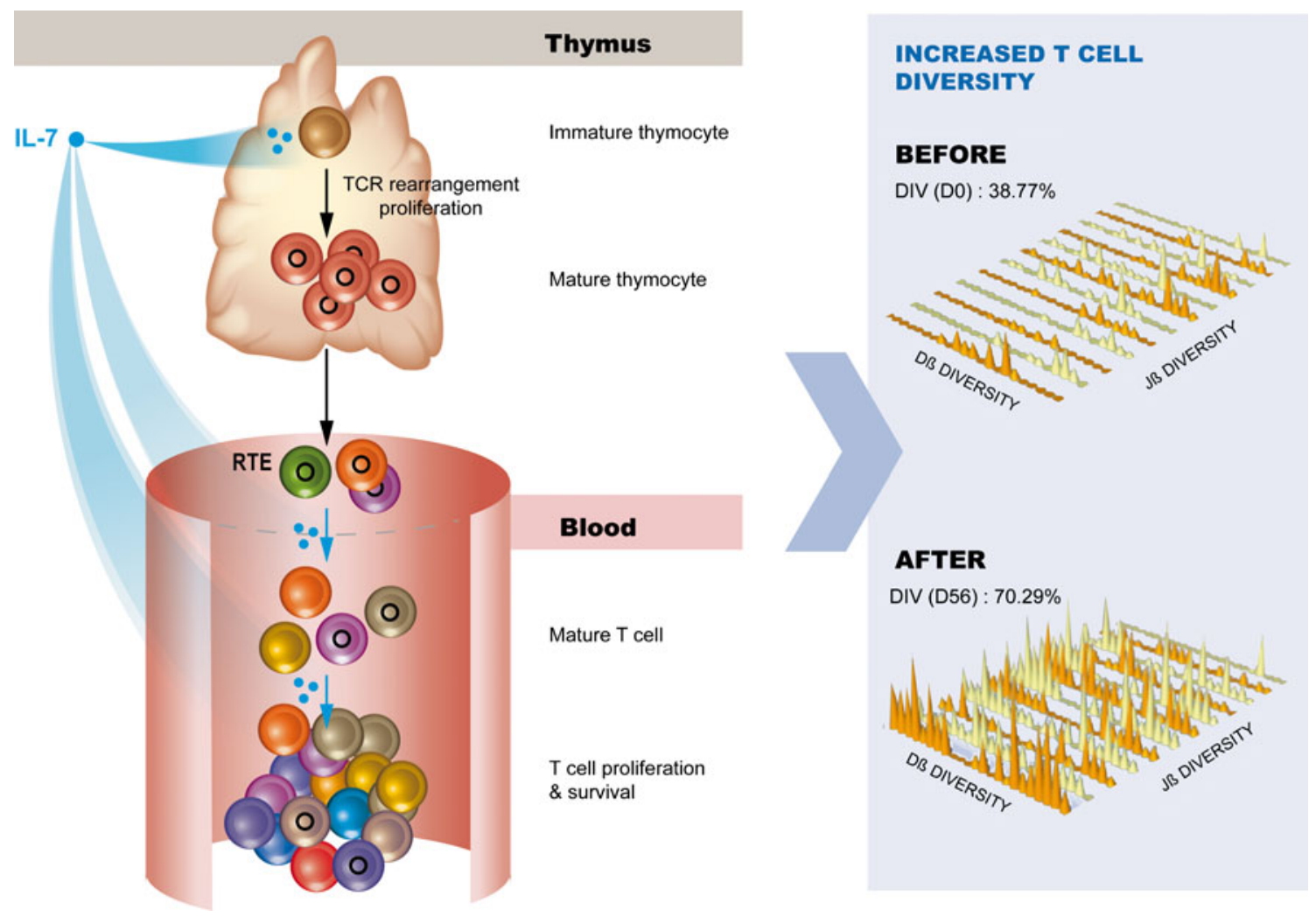

Fig. 3 Impact of IL-7 on T cell repertoire. IL-7 has a major role in preserving the naïve $\mathrm{T}$ cell repertoire by increasing thymopoiesis and cell viability in absence of antigen stimulation. Thymopoiesis increase was demonstrated by the increase of TRECs following IL-7 immunotherapy in HIV patients. By inducing a higher rate of thymocyte proliferation, the cytokine generates more diverse TCR rearrangement contributing to an increase of RTE and naive T cell subsets in the periphery. An increase of the T cell pool diversity was demonstrated by TCR beta combinational diversity in HIV-infected patients treated with IL-7(manuscript in preparation INSPIRE 1 study). Peripheral expansion of pre-existing T cells probably contributes to the TCR repertoire diversification observation. By increasing thymus activity, output, and peripheral expansion of produced cells IL-7 potentially increase T cell repertoire diversity 
thymopoietic activity) and later through the measure of $\mathrm{sj} /$ $\beta$ TRECs ratios, a marker reflecting the same effect but neutralizing the dilution due to the massive IL-7 T cell production (Fig. 3).

IL-7 therapy also produced memory T cells, effectors, and importantly for long-term protection central memory $\mathrm{T}$ cells

All these effects were consistent with the known presence of the IL-7 receptor on T cells, representing the sub population with the most receptors, naïve, and central memory, being preferentially expanded.

The proliferative effect measured by Ki67 was obvious in the early days of treatment and the anti-apoptotic effect of IL-7 guaranteed the stability of these effects. The distribution of these various subpopulations did not differ significantly when measured just after the treatment cycle or a few months after.

IL-7 therapy can increase the diversity of the T cell receptor repertoire: "the breadth dimension"

The observation of a thymopoietic effect confirmed earlier data sets produced in IL-7 treated monkeys as well as early thymic assessments performed on cancer patients. In addition to its lymphopoietic effect, IL-7 therapy can also raise clonal diversity by increasing the sensitivity of the TCR, not only to dominant epitopes, but also to sub-dominant epitopes as well [74-76]. The combination of these two effects results in an increased diversity of the TCR repertoire in treated patients. This was again assessed by utilizing the double PCR technology of ImmunID Technologies. The increase in TCR diversity has already been confirmed in HIV- and HCV-infected patients and after HSCT. These results also confirm previous data obtained by the immunoscope technology in cancer patients (Fig. 3). These increases in the diversity of the TCR repertoire are expected to increase the breadth of response against pathogens as well as against the escape of viruses by mutation and of malignant cells by immune editing.

IL-7 therapy can increase the homing of T cells to lymphoid tissues and target organs

Supporting previous data from experimental monkey studies, the measure of CD62L and $\alpha 4 \beta 7$ on T cells after IL-7 treatment confirmed their potential for migration to tissues. In fact, due to the massive T cell depletion observed in HIV-

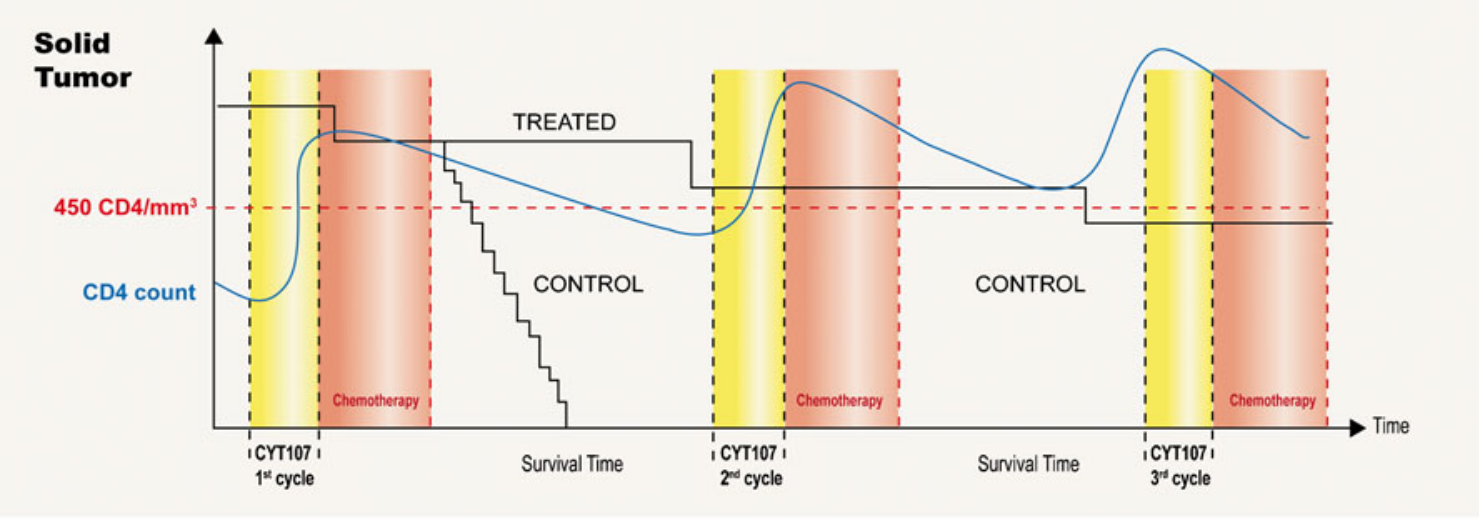

BMT

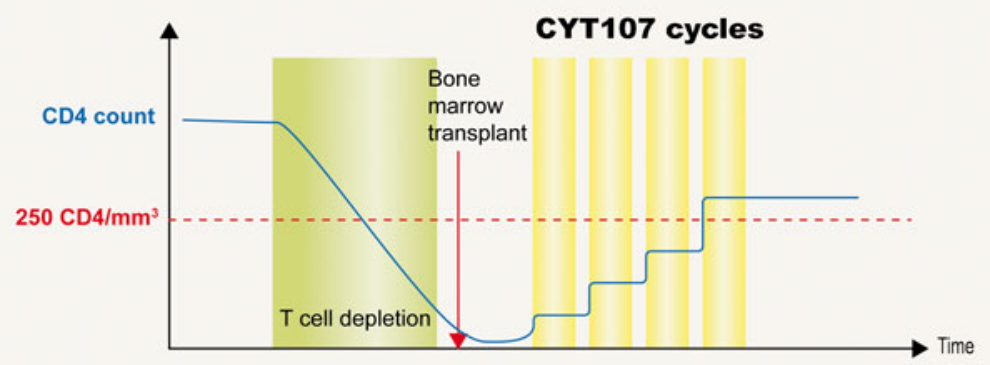

Fig. 4 Clinical trial design involving IL-7 immunotherapy. As lymphopenia was identified as a prognosis factor for overall survival and tumor progression in patients with advanced cancer, cycles of IL-7 could be used before chemotherapy intervention to restore global immunity. Two different types of cancer are envisaged here: solid tumor and bone marrow transplantation. In metastatic patients presenting a chemotherapy-induced lymphopenia, cycle of IL-7 before or during chemotherapy will counteract the lymphopenia effect and preserve $\mathrm{T}$ cell survival. Following $\mathrm{T}$ cell depletion in bone marrow transplanted patients, multiple cycles of IL-7 will be necessary to recover a competent immune system and reach a less life-threatening window 
infected patients and the key pathogenic role of this depletion in this disease and in the residual disease observed in immune non-responders to HAART, we were encouraged to measure the ability of IL-7 therapy to repopulate the gut with $T$ cells. This was confirmed by gut biopsies performed on these patients, showing a significant repopulation in most patients after just one 3-week cycle of treatment. These investigations are still ongoing and are being extended to patients receiving more than one IL-7 cycle in order to explore the stability of this $\mathrm{T}$ cell repopulation.

\section{Some interesting facets of IL-7 activity remain to be confirmed and detailed at the clinical level}

Though the expression of $\alpha 4 \beta 7$ allowing the extravasation of lymphocytes to the peripheral tissues certainly facilitates access to the tumor, fibrosis nevertheless remains a potential barrier, blocking access of $\mathrm{T}$ cells to their malignant targets. In his view, the IL-7 antagonism of TGF- $\beta$ and the resulting block of fibrosis observed in an experimental model (bleomycin-induced lung fibrosis) could represent an interesting aspect of IL-7 activity which remains to be demonstrated in the clinic [77]. Antagonizing the immune-suppressive of TGF- $\beta$ would also represent a positive trait of IL-7 anti-tumoral activity $[78,79]$.

Finally, the proliferative effects of IL-7 on the lymphocyte population are not limited to the $\alpha \beta$ T cells, as IL-7 also triggers the expansion of $\gamma \delta \mathrm{T}$ cells and invariant NKT. At the hinge between adaptive and innate immunity these cell populations certainly must participate in cancer immune surveillance, a feature that will be investigated in future clinical studies.

\section{Conclusions}

While anemia and platelet loss are quickly apparent to the clinician and call for immediate therapeutic correction, the case of lymphopenia is more surreptitious. Behind an apparent normal standard hematology cell count, a critical deficit can be hidden involving a global deficit of $\mathrm{T}$ cells (CD3), helper cells (CD4), or an oligoclonality, also known as "divpenia" for the loss of diversity. Together, these conditions open gaps in the immune repertoire or result in a deficit of migration which leaves substantial room for severe local lymphopenia in the vicinity of the tumor.

All along the dimensions of lymphopenia, preclinical and clinical data have accumulated to demonstrate the ability of exogeneous IL-7 therapy to repair these multiple deficits. With the availability of the first clinical results, there is now a high probability for demonstrating a true clinical benefit of IL-7 treatment in the most lymphopenic patients. The development of IL-7 therapy for the prevention of opportunistic infections and relapses or incidence of new malignancies is ongoing in the setting of post-HSCT and HIV infection. With the production of new data indicating short term post-chemotherapy survival of cancer patients with lymphopenia characterized by a loss of CD4 T cells or repertoire diversity (divpenia), a new therapeutic paradigm is beginning to open based on the role of the immune system in treating these cancer patients (Fig. 4). Though it is now obvious that a thrombocytopenia can lead to death by fatal hemorrhage, until recently it was much less obvious that loss of lymphocytes could also lead to death by a breakdown in the immune barrier to infectious agents or malignant cells, including metastatic cells.

Finally, in the current acceleration in the development of anticancer immunotherapies, most efforts have been deployed to trigger anti-malignant cell responses, a difficult task against cells made invisible to the immune system. The concept of immunoediting has been instrumental in advancing our understanding of how an efficient immune response can be insufficient and unstable. As a counter balance, then, it has now become clear that the addition of IL-7 support could bring to these developing immunotherapeutic approaches, the intensity, breadth, and stability needed to eliminate the malignant process before the advent of an efficient escape facilitated by immunoediting.

Acknowledgments The authors acknowledge R. Keatinge for reviewing text, A. Baudet and F. Gaudin for drawings. We also thank N. Pasqual, N. Plantier from ImmunId for TCR diversity figures.

Conflict of interest Michel Morre is CEO and shareholder of Cytheris S.A. Stephanie Beq is shareholder and employee of Cytheris S.A.

Open Access This article is distributed under the terms of the Creative Commons Attribution License which permits any use, distribution, and reproduction in any medium, provided the original author(s) and the source are credited.

\section{References}

1. Mackall CL, Fry TJ, Gress RE (2011) Harnessing the biology of IL-7 for therapeutic application. Nat Rev Immunol 11(5):330-342

2. Vesely MD, Kershaw MH, Schreiber RD, Smyth MJ (2011) Natural innate and adaptive immunity to cancer. Annu Rev Immunol 29:235-271

3. Mackall CL, Fleisher TA, Brown MR, Andrich MP, Chen CC, Feuerstein IM, Magrath IT, Wexler LH, Dimitrov DS, Gress RE (1997) Distinctions between CD8+ and CD4+ T-cell regenerative pathways result in prolonged T-cell subset imbalance after intensive chemotherapy. Blood 89(10):3700-3707

4. Mackall CL, Fleisher TA, Brown MR, Magrath IT, Shad AT, Horowitz ME, Wexler LH, Adde MA, McClure LL, Gress RE (1994) Lymphocyte depletion during treatment with intensive chemotherapy for cancer. Blood 84(7):2221-2228

5. Blay JY, Chauvin F, Le Cesne A, Anglaret B, Bouhour D, Lasset C, Freyer G, Philip T, Biron P (1996) Early lymphopenia after 
cytotoxic chemotherapy as a risk factor for febrile neutropenia. $\mathrm{J}$ Clin Oncol 14(2):636-643

6. Borg C, Ray-Coquard I, Philip I, Clapisson G, Bendriss-Vermare N, Menetrier-Caux C, Sebban C, Biron P, Blay JY (2004) CD4 lymphopenia as a risk factor for febrile neutropenia and early death after cytotoxic chemotherapy in adult patients with cancer. Cancer 101(11):2675-2680

7. Ray-Coquard I, Borg C, Bachelot T, Sebban C, Philip I, Clapisson G, Le Cesne A, Biron P, Chauvin F, Blay JY (2003) Baseline and early lymphopenia predict for the risk of febrile neutropenia after chemotherapy. Br J Cancer 88(2):181-186

8. Bedimo RJ, McGinnis KA, Dunlap M, Rodriguez-Barradas MC, Justice AC (2009) Incidence of non-AIDS-defining malignancies in HIV-infected versus noninfected patients in the HAART era: impact of immunosuppression. J Acquir Immune Defic Syndr 52(2):203-208

9. Marin B, Thiebaut R, Bucher HC, Rondeau V, Costagliola D, Dorrucci M, Hamouda O, Prins M, Walker S, Porter K, Sabin C, Chene G (2009) Non-AIDS-defining deaths and immunodeficiency in the era of combination antiretroviral therapy. AIDS 23(13):1743-1753

10. Smith C, Sabin CA, Lundgren JD, Thiebaut R, Weber R, Law M, Monforte A, Kirk O, Friis-Moller N, Phillips A, Reiss P, El Sadr W, Pradier C, Worm SW (2010) Factors associated with specific causes of death amongst HIV-positive individuals in the D:A:D Study. AIDS 24(10):1537-1548

11. Monforte A, Abrams D, Pradier C, Weber R, Reiss P, Bonnet F, Kirk O, Law M, De Wit S, Friis-Moller N, Phillips AN, Sabin CA, Lundgren JD (2008) HIV-induced immunodeficiency and mortality from AIDS-defining and non-AIDS-defining malignancies. AIDS 22(16):2143-2153

12. Chen LJ, Sun J, Wu HY, Zhou SM, Tan Y, Tan M, Shan BE, Lu BF, Zhang XG (2011) B7-H4 expression associates with cancer progression and predicts patient's survival in human esophageal squamous cell carcinoma. Cancer Immunol Immunother 60(7):1047-1055

13. Schreiber RD, Old LJ, Smyth MJ (2011) Cancer immunoediting: integrating immunity's roles in cancer suppression and promotion. Science 331(6024): 1565-1570

14. Pasqual N, Gallagher M, Aude-Garcia C, Loiodice M, Thuderoz F, Demongeot J, Ceredig R, Marche PN, Jouvin-Marche E (2002) Quantitative and qualitative changes in V-J alpha rearrangements during mouse thymocytes differentiation: implication for a limited T cell receptor alpha chain repertoire. J Exp Med 196(9):1163-1173

15. Achhra AC, Amin J, Law MG, Emery S, Gerstoft J, Gordin FM, Vjecha MJ, Neaton JD, Cooper DA (2010) Immunodeficiency and the risk of serious clinical endpoints in a well studied cohort of treated HIV-infected patients. AIDS 24(12):1877-1886

16. Guadalupe M, Reay E, Sankaran S, Prindiville T, Flamm J, McNeil A, Dandekar S (2003) Severe CD4+ T-cell depletion in gut lymphoid tissue during primary human immunodeficiency virus type 1 infection and substantial delay in restoration following highly active antiretroviral therapy. J Virol 77(21):11708-11717

17. Brenchley JM, Schacker TW, Ruff LE, Price DA, Taylor JH, Beilman GJ, Nguyen PL, Khoruts A, Larson M, Haase AT, Douek DC (2004) CD4+ T cell depletion during all stages of HIV disease occurs predominantly in the gastrointestinal tract. J Exp Med 200(6):749-759

18. Zeng M, Smith AJ, Wietgrefe SW, Southern PJ, Schacker TW, Reilly CS, Estes JD, Burton GF, Silvestri G, Lifson JD, Carlis JV, Haase AT (2011) Cumulative mechanisms of lymphoid tissue fibrosis and T cell depletion in HIV-1 and SIV infections. J Clin Invest 121(3):998-1008

19. Grulich AE, van Leeuwen MT, Falster MO, Vajdic CM (2007) Incidence of cancers in people with HIV/AIDS compared with immunosuppressed transplant recipients: a meta-analysis. Lancet 370(9581):59-67

20. Dauby N, De Wit S, Delforge M, Necsoi VC, Clumeck N (2011) Characteristics of non-AIDS-defining malignancies in the HAART era: a clinico-epidemiological study. J Int AIDS Soc 14:16
21. Ray-Coquard I, Cropet C, Van Glabbeke M, Sebban C, Le Cesne A, Judson I, Tredan O, Verweij J, Biron P, Labidi I, Guastalla JP, Bachelot T, Perol D, Chabaud S, Hogendoorn PC, Cassier P, Dufresne A, Blay JY (2009) Lymphopenia as a prognostic factor for overall survival in advanced carcinomas, sarcomas, and lymphomas. Cancer Res 69(13):5383-5391

22. Porrata LF, Ristow K, Habermann T, Inwards DJ, Micallef IN, Markovic SN (2010) Predicting survival for diffuse large B-cell lymphoma patients using baseline neutrophil/lymphocyte ratio. Am J Hematol 85(11):896-899

23. Ceze N, Thibault G, Goujon G, Viguier J, Watier H, Dorval E, Lecomte T (2011) Pre-treatment lymphopenia as a prognostic biomarker in colorectal cancer patients receiving chemotherapy. Cancer Chemother Pharmacol 68(5):1305-1313

24. Lim SM, Kim YR, Park JS, Park HS, Lim JY, Cho JY (2011) The prognositc value of lymphopenia in advanced gastric cancer. ASCO Meeting Abstracts 29(15_suppl):e14500

25. Desposorio CR, Hurtado de Mendoza F, Falcon SG, Capellino AR, Lujan R, Morales D, Castillo JJ, Beltran BE (2011) Lymphopenia as a predictive factor of responsiveness to preoperative treatment in patients with locally advanced breast cancer. ASCO Meeting Abstracts 29(15_suppl):e21096

26. Capellino AR, Desposorio CR, Hurtado de Mendoza F, Falcon SG, Beltran BE, Lujan R, Morales D, Castillo JJ (2011) Lymphopenia and breast cancer subtypes as prognostic factors in patients with locally advanced breast cancer. ASCO Meeting Abstracts 29 (15_suppl):e21100

27. Peron J, Ray-Coquard IL, Labidi-Galy SI, Heudel P, Clapisson G, Cassier PA, Philip I, Borg C, Tredan O, Bachelot TD, Sebban C, Ghesquieres H, Menetrier-Caux C, Caux C, Biron P, Blay J (2011) Association of CD4 lymphopenia with survival in patients with advanced cancer. ASCO Meeting Abstracts 29(15_suppl):e21145

28. Miwa H (1984) Identification and prognostic implications of tumor infiltrating lymphocytes - a review. Acta Med Okayama 38 (3):215-218

29. Hsu MM (1990) Local infiltration of T-lymphocyte subsets as a prognostic indicator in patients with nasopharyngeal carcinoma. Ear Nose Throat J 69(8):543-547

30. Tsujihashi H, Uejima S, Akiyama T, Kurita T (1989) Immunohistochemical detection of tissue-infiltrating lymphocytes in bladder tumors. Urol Int 44(1):5-9

31. Fridman WH, Galon J, Dieu-Nosjean MC, Cremer I, Fisson S, Damotte D, Pages F, Tartour E, Sautes-Fridman C (2011) Immune infiltration in human cancer: prognostic significance and disease control. Curr Top Microbiol Immunol 344:1-24

32. Jochems C, Schlom J (2011) Tumor-infiltrating immune cells and prognosis: the potential link between conventional cancer therapy and immunity. Exp Biol Med (Maywood) 236(5):567-579

33. Pages F, Galon J, Dieu-Nosjean MC, Tartour E, Sautes-Fridman C, Fridman WH (2010) Immune infiltration in human tumors: a prognostic factor that should not be ignored. Oncogene 29 (8):1093-1102

34. Sorbye SW, Kilvaer T, Valkov A, Donnem T, Smeland E, Al-Shibli K, Bremnes RM, Busund LT (2011) Prognostic impact of lymphocytes in soft tissue sarcomas. PLoS One 6(1):e14611

35. Pages F, Berger A, Camus M, Sanchez-Cabo F, Costes A, Molidor R, Mlecnik B, Kirilovsky A, Nilsson M, Damotte D, Meatchi T, Bruneval P, Cugnenc PH, Trajanoski Z, Fridman WH, Galon J (2005) Effector memory T cells, early metastasis, and survival in colorectal cancer. N Engl J Med 353(25):2654-2666

36. Hodi FS, Dranoff G (2010) The biologic importance of tumorinfiltrating lymphocytes. J Cutan Pathol 37(Suppl 1):48-53

37. Kim HI, Kim H, Cho HW, Kim SY, Song KJ, Hyung WJ, Park CG, Kim CB (2011) The ratio of intra-tumoral regulatory $\mathrm{T}$ cells $($ Foxp3 + )/helper T cells $(\mathrm{CD} 4+)$ is a prognostic factor and associated with recurrence pattern in gastric cardia cancer. J Surg Oncol 
38. Ascierto PA, Simeone E, Sznol M, Fu YX, Melero I (2010) Clinical experiences with anti-CD137 and anti-PD1 therapeutic antibodies. Semin Oncol 37(5):508-516

39. Kline J, Gajewski TF (2010) Clinical development of mAbs to block the PD1 pathway as an immunotherapy for cancer. Curr Opin Investig Drugs 11(12):1354-1359

40. Goodwin RG, Namen A (1989) The cloning and characterization of interleukin7. Year Immunol 6:127

41. Fry TJ, Mackall C (2002) Interleukin-7: from bench to clinic. Blood 99(11):3892-3904

42. Borghesi LA, Yamashita Y, Kincade PW (1999) Heparan sulfate proteoglycans mediate interleukin-7-dependent B lymphopoiesis. Blood 93(1):140-148

43. Peschon JJ, Morrissey PJ, Grabstein KH, Ramsdell FJ, Maraskovsky E, Gliniak BC, Park LS, Ziegler SF, Williams DE, Ware CB, Meyer JD, Davison BL (1994) Early lymphocyte expansion is severely impaired in interleukin 7 receptor-deficient mice. J Exp Med 180 (5):1955-1960

44. von Freeden-Jeffry U, Vieira P, Lucian LA, McNeil T, Burdach SE, Murray R (1995) Lymphopenia in interleukin (IL)-7 gene-deleted mice identifies IL-7 as a nonredundant cytokine. J Exp Med 181 (4):1519-1526

45. Plum J, De Smedt M, Leclercq G, Verhasselt B, Vandekerckhove B (1996) Interleukin-7 is a critical growth factor in early human Tcell development. Blood 88(11):4239-4245

46. Li J, Nara H, Rahman M, Juliana FM, Araki A, Asao H (2010) Impaired IL-7 signaling may explain a case of atypical JAK3SCID. Cytokine 49(2):221-228

47. Puel A, Ziegler SF, Buckley RH, Leonard WJ (1998) Defective IL7R expression in $\mathrm{T}(-) \mathrm{B}(+) \mathrm{NK}(+)$ severe combined immunodeficiency. Nat Genet 20(4):394-397

48. Roifman CM, Zhang J, Chitayat D, Sharfe N (2000) A partial deficiency of interleukin-7R alpha is sufficient to abrogate T-cell development and cause severe combined immunodeficiency. Blood 96(8):2803-2807

49. Rossberg S, Schwarz K, Meisel C, Holzhauer S, Kuhl J, Ebell W, Wahn V, von Bernuth H (2009) Delayed onset of (severe) combined immunodeficiency (S)CID (T-B+NK+): complete IL-7 receptor deficiency in a 22 months old girl. Klin Padiatr 221(6):339 343

50. Fry TJ, Mackall CL (2001) Interleukin-7: master regulator of peripheral T-cell homeostasis? Trends Immunol 22(10):564-571

51. Fry TJ, Connick E, Falloon J, Lederman MM, Liewehr DJ, Spritzler J, Steinberg SM, Wood LV, Yarchoan R, Zuckerman J, Landay A, Mackall CL (2001) A potential role for interleukin-7 in T-cell homeostasis. Blood 97(10):2983-2990

52. Napolitano LA, Grant RM, Deeks SG, Schmidt D, De Rosa SC, Herzenberg LA, Herndier BG, Andersson J, McCune JM (2001) Increased production of IL-7 accompanies HIV-1-mediated T-cell depletion: implications for T-cell homeostasis. Nat Med 7(1):73-79

53. Kittipatarin C, Khaled AR (2007) Interlinking interleukin-7. Cytokine 39(1):75-83

54. Schluns KS, Kieper W, Jameson SC, Lefrançois L (2000) Interleukin-7 mediates the homeostasis of naïve and memory CD8 T cells in vivo. Nat Immunol 1(5):426-432

55. Morrissey PJ, Conlon P, Braddy S, Williams DE, Namen AE, Mochizuki DY (1991) Administration of IL-7 to mice with cyclophosphamide-induced lymphopenia accelerates lymphocyte repopulation. J Immunol 146(5):1547-1552

56. Alpdogan O, Schmaltz C, Muriglan SJ, Kappel BJ, Perales MA, Rotolo JA, Halm JA, Rich BE, van den Brink MR (2001) Administration of interleukin-7 after allogeneic bone marrow transplantation improves immune reconstitution without aggravating graftversus-host disease. Blood 98(7):2256-2265

57. Storek J, Gillespy T 3rd, Lu H, Joseph A, Dawson MA, Gough M, Morris J, Hackman RC, Horn PA, Sale GE, Andrews RG, Maloney
DG, Kiem HP (2003) Interleukin-7 improves CD4 T-cell reconstitution after autologous CD34 cell transplantation in monkeys. Blood 101(10):4209-4218

58. Beq S, Nugeyre MT, Ho Tsong Fang R, Gautier D, Legrand R, Schmitt N, Estaquier J, Barre-Sinoussi F, Hurtrel B, Cheynier R, Israel N (2006) IL-7 induces immunological improvement in SIVinfected rhesus macaques under antiviral therapy. J Immunol 176 (2):914-922

59. Fry TJ, Moniuszko M, Creekmore S, Donohue SJ, Douek DC, Giardina S, Hecht TT, Hill BJ, Komschlies K, Tomaszewski J, Franchini G, Mackall CL (2003) IL-7 therapy dramatically alters peripheral T-cell homeostasis in normal and SIV-infected nonhuman primates. Blood 101(6):2294-2299

60. Leone A, Rohankhedkar M, Okoye A, Legasse A, Axthelm MK, Villinger F, Piatak M Jr, Lifson JD, Assouline B, Morre M, Picker LJ, Sodora DL (2010) Increased CD4+ T cell levels during IL-7 administration of antiretroviral therapy-treated simian immunodeficiency virus-positive macaques are not dependent on strong proliferative responses. J Immunol 185(3):1650-1659

61. Parker R, Dutrieux J, Beq S, Lemercier B, Rozlan S, FabreMersseman V, Rancez M, Gommet C, Assouline B, Rance I, Lim A, Morre M, Cheynier R (2010) Interleukin-7 treatment counteracts IFN-alpha therapy-induced lymphopenia and stimulates SIVspecific cytotoxic T lymphocyte responses in SIV-infected rhesus macaques. Blood 116(25):5589-5599

62. Henriques CM, Rino J, Nibbs RJ, Graham GJ, Barata JT (2010) IL-7 induces rapid clathrin-mediated internalization and JAK3dependent degradation of IL-7Ralpha in T cells. Blood 115 (16):3269-3277

63. Beq S, Rozlan S, Gautier D, Parker R, Mersseman V, Schilte C, Assouline B, Rance I, Lavedan P, Morre M, Cheynier R (2009) Injection of glycosylated recombinant simian IL-7 provokes rapid and massive T-cell homing in rhesus macaques. Blood 114(4):816825

64. Li B, VanRoey MJ, Jooss K (2007) Recombinant IL-7 enhances the potency of GM-CSF-secreting tumor cell immunotherapy. Clin Immunol 123(2):155-165

65. Pellegrini M, Calzascia T, Elford AR, Shahinian A, Lin AE, Dissanayake D, Dhanji S, Nguyen LT, Gronski MA, Morre M, Assouline B, Lahl K, Sparwasser T, Ohashi PS, Mak TW (2009) Adjuvant IL-7 antagonizes multiple cellular and molecular inhibitory networks to enhance immunotherapies. Nat Med 15(5):528536

66. Dillman RO (2011) Cancer immunotherapy. Cancer Biother Radiopharm 26(1):1-64

67. Abrams D, Levy Y, Losso MH, Babiker A, Collins G, Cooper DA, Darbyshire J, Emery S, Fox L, Gordin F, Lane HC, Lundgren JD, Mitsuyasu R, Neaton JD, Phillips A, Routy JP, Tambussi G, Wentworth D (2009) Interleukin-2 therapy in patients with HIV infection. N Engl J Med 361(16):1548-1559

68. Weiss L, Letimier FA, Carriere M, Maiella S, Donkova-Petrini V, Targat B, Benecke A, Rogge L, Levy Y (2010) In vivo expansion of naive and activated $\mathrm{CD} 4+\mathrm{CD} 25+\mathrm{FOXP} 3+$ regulatory $\mathrm{T}$ cell populations in interleukin-2-treated HIV patients. Proc Natl Acad Sci U S A 107(23):10632-10637

69. Malek TR, Castro I (2010) Interleukin-2 receptor signaling: at the interface between tolerance and immunity. Immunity 33(2):153165

70. Fry TJ, Mackall CL (2005) The many faces of IL-7: from lymphopoiesis to peripheral T cell maintenance. J Immunol 174(11):65716576

71. Menetrier-Caux C, Gobert M, Caux C (2009) Differences in tumor regulatory T-cell localization and activation status impact patient outcome. Cancer Res 69(20):7895-7898

72. Suzuki H, Kundig TM, Furlonger C, Wakeham A, Timms E, Matsuyama T, Schmits R, Simard JJ, Ohashi PS, Griesser H et al 
(1995) Deregulated T cell activation and autoimmunity in mice lacking interleukin-2 receptor beta. Science 268(5216):1472-1476

73. Kramer S, Schimpl A, Hunig T (1995) Immunopathology of interleukin (IL) 2-deficient mice: thymus dependence and suppression by thymus-dependent cells with an intact IL-2 gene. J Exp Med 182(6):1769-1776

74. Gagnon J, Chen XL, Forand-Boulerice M, Leblanc C, Raman C, Ramanathan S, Ilangumaran S (2010) Increased antigen responsiveness of naive CD8 T cells exposed to IL-7 and IL-21 is associated with decreased CD5 expression. Immunol Cell Biol 88(4):451-460

75. Melchionda F, Fry TJ, Milliron MJ, McKirdy MA, Tagaya Y, Mackall CL (2005) Adjuvant IL-7 or IL-15 overcomes immunodominance and improves survival of the CD8+ memory cell pool. $\mathrm{J}$ Clin Invest 115(5):1177-1187

76. Palmer MJ, Mahajan VS, Chen J, Irvine DJ, Lauffenburger DA (2011) Signaling thresholds govern heterogeneity in IL-7-receptor-mediated responses of naive CD8(+) T cells. Immunol Cell Biol 89(5):581-594

77. Huang M, Sharma S, Zhu LX, Keane MP, Luo J, Zhang L, Burdick MD, Lin YQ, Dohadwala M, Gardner B, Batra RK, Strieter RM, Dubinett SM (2002) IL-7 inhibits fibroblast TGF-beta production and signaling in pulmonary fibrosis. J Clin Invest 109(7):931-937

78. Takaku S, Terabe M, Ambrosino E, Peng J, Lonning S, McPherson JM, Berzofsky JA (2010) Blockade of TGF-beta enhances tumor vaccine efficacy mediated by CD8(+) T cells. Int J Cancer 126 (7):1666-1674

79. Terabe M, Ambrosino E, Takaku S, O'Konek JJ, Venzon D, Lonning S, McPherson JM, Berzofsky JA (2009) Synergistic enhancement of
CD8+ T cell-mediated tumor vaccine efficacy by an antitransforming growth factor-beta monoclonal antibody. Clin Cancer Res 15(21):6560-6569

80. Levy Y, Lacabaratz C, Weiss L, Viard JP, Goujard C, Lelievre JD, Boue F, Molina JM, Rouzioux C, Avettand-Fenoel V, Croughs T, Beq S, Thiebaut R, Chene G, Morre M, Delfraissy JF (2009) Enhanced T cell recovery in HIV-1-infected adults through IL-7 treatment. J Clin Invest 119(4):997-1007

81. Sportes C, Gress RE, Mackall CL (2009) Perspective on potential clinical applications of recombinant human interleukin-7. Ann N Y Acad Sci 1182:28-38

82. Sereti I, Dunham RM, Spritzler J, Aga E, Proschan MA, Medvik K, Battaglia CA, Landay AL, Pahwa S, Fischl MA, Asmuth DM, Tenorio AR, Altman JD, Fox L, Moir S, Malaspina A, Morre M, Buffet R, Silvestri G, Lederman MM (2009) IL-7 administration drives T cell-cycle entry and expansion in HIV-1 infection. Blood 113(25):6304-6314

83. Sportes C, Hakim FT, Memon SA, Zhang H, Chua KS, Brown MR, Fleisher TA, Krumlauf MC, Babb RR, Chow CK, Fry TJ, Engels J, Buffet R, Morre M, Amato RJ, Venzon DJ, Korngold R, Pecora A, Gress RE, Mackall CL (2008) Administration of rhIL-7 in humans increases in vivo TCR repertoire diversity by preferential expansion of naive T cell subsets. J Exp Med 205(7):17011714

84. Sakaguchi S, Wing K, Onishi Y, Prieto-Martin P, Yamaguchi T (2009) Regulatory T cells: how do they suppress immune responses? Int Immunol 21(10):1105-1111 